\title{
The Impact of Labor Mobility on Living Standard: an Empirical Study on the Northern Region of Bangladesh
}

\section{Omar Faruque}

Omar Faruque, Associate Professor, Department of Accounting and Information Systems, Begum Rokeya University, Rangpur, BANGLADESH

*Corresponding Contact:

Email: faruque1712@gmail.com

\begin{abstract}
In the past ten years, Bangladesh has experienced positive economic and social changes. Historically, labor mobility has been a common livelihood strategy of the people and the Bangladeshi people. The mobility of labor has become an important part of the current world economy. The primary objective of this study is to provide a review of the impact of labor mobility on living standards in the northern region of Bangladesh. To develop the paper, primary and secondary data are collected. The quantitative and qualitative analyses are conducted in this study. Primary data is collected through a set of well-structured questionnaires. In the study, it is observed that there are $8 \%$ of labor who have migrated within the last three years. From 2011 to 2015 , the maximum laborers are migrated, i.e., $37 \%$ and $33 \%$ of migrated labor were day labor. There are $35.56 \%$ of people with zero income level per day before their migration. On the other hand, after the migration, there are no people with nil income. Before the migration $81.11 \%$ of people incur their expenditure for buying the inferior goods and the rest of the people incur for the necessity goods, but no one can consume the luxurious goods. On the other hand, after the migration, only $4.44 \%$ of laborers are availing the luxurious goods. So still they are not enjoying their life. Before the migrations there are $9 \%$ of people who are extremely dissatisfied with these types of facilities, and $33.33 \%$ of people were very dissatisfied. On the other hand, there are $23.33 \%$ of labors who are very pleased with their medical facilities, shelter and child education facilities. The result shows that, $41 \%$ of people are pushed for migration. It is assumed that, there is a great impact of labor mobilization on the living standards. The labor is migrated to have better living standards. There are two alternatives for their survivals, first we have to provide the job opportunities near their residence, and the alternative is to provide the better living standard for the migrated people.
\end{abstract}

Key Words: Labor Mobilization, Remittance, Living Standard, Productivity

\section{INTRODUCTION}

In the past ten years, Bangladesh has experienced positive economic and social changes. Historically, labor mobility has been a common livelihood strategy of the people and the Bangladeshi people (Briggs, 1994). Since the 18th century, labor mobility from Bangladesh has had a direct correlation with economic development (Chowdhury et al., 2010; Faruque and Ali, 2016). During the 1970s, the labor markets in the Middle East offered new scope for Bangladeshi migrant labor. Later, such migration also expanded to the newly industrialized 
countries of South East Asia. Nowadays, labor mobility within the national boundaries also plays a vital role for the whole economy (Bing, 2011). Labor mobility is an important livelihood strategy for poor people of a developing country while ensuring that migrant workers receive the maximum protection (Leeson \& Gochenour, 2015; Rahman, 2014).

Labor mobility has become an integral part of the current global economy. Both internal and international Labor mobility can have major development and poverty implications for individuals and their families (Faruque \& Rahman, 2021). It is very important for origin and destination areas, and for national economies.

A recent Human Development Report estimated that the number of internal migrants is about four times the total number of international migrants (UNDP 2009). Internal migration, especially in large countries like India and China, can be across very substantial distances. According to Investopedia, labor mobility refers to the ease with which laborers can move around within an economy and between different economies. It is an important factor in economics because it looks at how labor, one of the major factors of production, affects growth and production (Faruque, 2021). There are two primary types of labor mobility: geographic and occupational. Geographic mobility refers to a worker's ability to work in a particular physical location, while occupational mobility refers to a worker's ability to change job types. For example, a worker moving from the United States to Bangladesh involves the concept of geographic mobility. An automobile mechanic who changes jobs to become an airline pilot involves the concept of occupational mobility.

Living standard depends on the level of income. And the income level depends on the occupation. But nowadays, the world is facing the problem of efficient labor. Labor is a very important factor of production. A producer needs experienced and skilled labor. On the other hand, unemployed persons are seeking employment with a handsome salary. For the proper development of an economy, equilibrium of labor demand and supply is must (Faruque \& Rahman, 2021).

An employment with a handsome salary can change the lifestyle and living standard of a people and for the whole nation. The main intention of the labor mobility is to exist, survive and then change their living standard. There is an impact of labor mobility on the standards of living of an employee and his family. But it is too tough to assess the impact in a numerical value. Naturally, no one wishes to leave his homeland. But for his existence and to change the living standard, the situation makes them bound to leave.

\section{Objectives of the Study}

The primary objective of this study is to provide a review of the impact of labor mobility on living standards in the northern region of Bangladesh.

The other specific objectives are as follows:

- $\quad$ To assess the impact of labor mobility on improving their living standard.

- To provide policy recommendations for a desirable level of national labor mobility.

\section{LITERATURE REVIEW}

Nowadays, as an important part of production labor is must for our existence. For that, labor mobility is now a very burning issue in the world. The world is suffering from shortage of labor. The other world is suffering the surpluses of it. This demand and supply should be matched and this matching is deficit. 
Hossain (2010) cited that, skilled migrants have higher poverty-reducing impact than unskilled migrants. For overseas occupation of the migrants unskilled to skilled the log odds ratio of the households being poor is decreased by 1.6. This shows the important role of skilled migrants in reducing poverty.

Wilson (2012) stated that, increasing the mobility of humans is the best way to not only promote economic efficiency, but to provide freedom and significant improvements in their wellbeing and quality of life.

David \& Marouani (2013) develops a dynamic general equilibrium framework for each economy, with full-fledged modeling of migration, labor market and education issues. The study also stated that, an increase in foreign wages has higher benefits in Jordan, despite of higher induced migration increase in Tunisia. When the rise is limited to high-skilled migrants' wages, low and medium-skilled workers are positively affected in Tunisia and negatively in Jordan.

Srivastava \& Sasikumar (2003) deals with internal and international migration, both of which are large-scale with impacts on economic growth and poverty reduction in many regions of the country. In some parts of India, three out of four households include a migrant. However despite the large scale of migration in absolute numbers of people involved and India's long history of population and labor mobility, labor migration has rarely been reliably studied.

Abella (2013) looks at how Diaspora communities have served as sources of information, linkages, or networks with businesses, markets for sovereign bonds, mediums for the transfer of technology and know-how, and a tourism market.

Labor Migration trends and Patterns: Bangladesh, India, and Nepal (The Asia Foundation, 2013) revealed that Nepali migrants pay much less for migration than Bangladeshi migrants. Furthermore, high financial costs and high-interest rates invariably lead to large debts even if migrants work abroad. Migrants in both countries have little access to secure loans from formal financial institutions to facilitate their migration. Hence, they are compelled to secure loans from informal channels with staggering interest rates levied on them, placing them in a highly risky situation where they are required to earn all the invested money to repay the loan in full and the ensure savings within the duration of employment (Ministry of Expatriates, 2020). Many migrants had the firm belief that it was impossible to predict income since, in their eyes, luck or faith played an important role in migration. This puts them in a highly vulnerable and risky situation because they are obligated to earn money to repay the loans and raise necessary funds as savings from their families back home within the pre-decided span of their stay in the destination country. The study revealed the importance of having a bank account to maintain control over a migrant's own remittance and savings.

Ratha et al. (2013) provides a review of the literature on the development impact of migration and remittances on origin countries and on destination countries in the South. International migration is an ever-growing phenomenon that has important development implications for both sending and receiving countries.

International Labor Organization (2015) stated that, migrants pay more taxes and social contributions than they receive and contribute substantively to destination countries' economies, by providing the labor and skills needed in critical occupations and sectors. Across the advanced countries, the number of highly-educated immigrants has increased rapidly over the past decade, which has important implications for productivity and innovation. Migrants could play a role in facilitating trade and investment flows. Through the 
contribution of remittances, child labor could be reduced and schooling financed. Return migrants have the potential to make a positive contribution to the economic development in their countries of origin through the human, social and financial capital acquired abroad (Faruque \& Siddiqua, 2019).

Siddiqui (2012) reviews that, the literature on migration in South Asia, Southeast Asia, Southern Africa, East Africa and West Africa to highlight the complexity of migration patterns and impacts. It is also accompanied, where relevant, by evidence from Latin America and the Caribbean. It draws attention to the many types of migration including: internal migration, short-term international contract labor; cross-border mobility and regional migration and the different impacts that they have at the household level and beyond. The findings are presented in fewer than five broad headings: the impact of migration on individual migrants; left behind family members; community; local economies; and national economies of origin. The review was undertaken to inform the research strategy of the Migrating out of Poverty Research Program Consortium.

Siddiqui (2003) examines the experiences of the government, private sector, and civil society in managing international emigration from Bangladesh. The paper outlines complex processes of labor migration. It identifies where policy interventions may make international migration an important livelihood strategy for poor people while ensuring that migrant workers receive the maximum protection both at home and abroad. It describes the extent, nature and types of both short and long-term international migration.

Thus, the present study is designed to overcome the above gap and add some new findings with its existing literature.

\section{Methodology of the Study}

To develop the paper, primary and secondary data are collected. The quantitative and qualitative analyses are conducted. From 1976 to 2015, there 96,98,687 laborers are migrated in abroad from Bangladesh. It is the figure of international labor mobility. On the other hand, every year, a large number of labors are migrated from the northern region to other sides of the states. The national labors, who have migrated within the boundary of Bangladesh are considered the total population for this study. Among the large number of national migrated people, 90 labors comprising skilled migrants and unskilled migrants is selected randomly as the sample of this study purpose.

Primary data is collected through a set of well-structured questionnaires. To collect the primary data, personal survey method is used. This process is focused on group meetings with the various stakeholders. The secondary data is collected from various websites, economic news, related journals, books, official statistics, published brochures, prospects, the dailies, and websites. Computerized modern technology is used in coding, tabulating and processing data. SPSS and other statistical tools and techniques are used in data analysis process.

\section{Data ANALYSIS AND Discussion}

The data collected from the survey the following findings and discussions are made. From the observed data various types of analysis is made. From the various points of view it is shown that the conditions of the labor mobility condition of the northern reason of Bangladesh. 


\section{Location of the labor}

The obtained data shows that, there are 7 districts labor are available, of which the maximum data the Nilphamary district. The sample size is 90 , of these every sample district contains at least $10 \%$ of the total sample labor.

Table 1: District wise data analysis

\begin{tabular}{|l|c|c|}
\hline \multicolumn{1}{|c|}{ District } & No. of Labors & $\mathbf{\%}$ \\
\hline Rangpur & 13 & 14.44 \\
\hline Lalmonirhat & 15 & 16.67 \\
\hline Nilphamary & 25 & 27.78 \\
\hline Gaibandha & 9 & 10.00 \\
\hline Panchgarh & 9 & 10.00 \\
\hline Dinajpur & 9 & 10.00 \\
\hline Kurigram & 10 & 11.11 \\
\hline Total & 90 & 100.00 \\
\hline
\end{tabular}

Source: Constructed from Questionnaire Survey

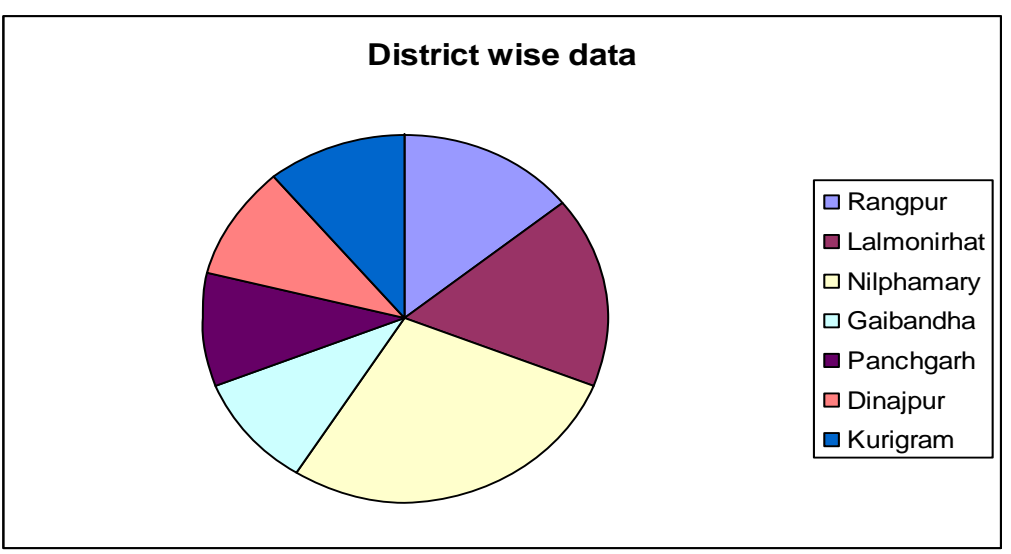

Figure 1: District wise data analysis

Source: Constructed from Questionnaire Survey

\section{Age of the labor}

The study shows that, there are some labors, whose age is below 20years and who have migrated from their native village for their livelihood. It is also shown by the data that more than one percent laborers are very aged, whose age is over 50 years. The age range 20-30 shows the height frequency, i.e., 47 out of 90.

Table 2: Age of the labor

\begin{tabular}{|c|c|}
\hline Age of the Labor & No. of Frequency \\
\hline Below 20 & 3 \\
\hline $20-30$ & 47 \\
\hline $31-40$ & 27 \\
\hline $41-50$ & 12 \\
\hline $51-60$ & 1 \\
\hline Total & 90 \\
\hline
\end{tabular}

Source: Constructed from Questionnaire Survey 


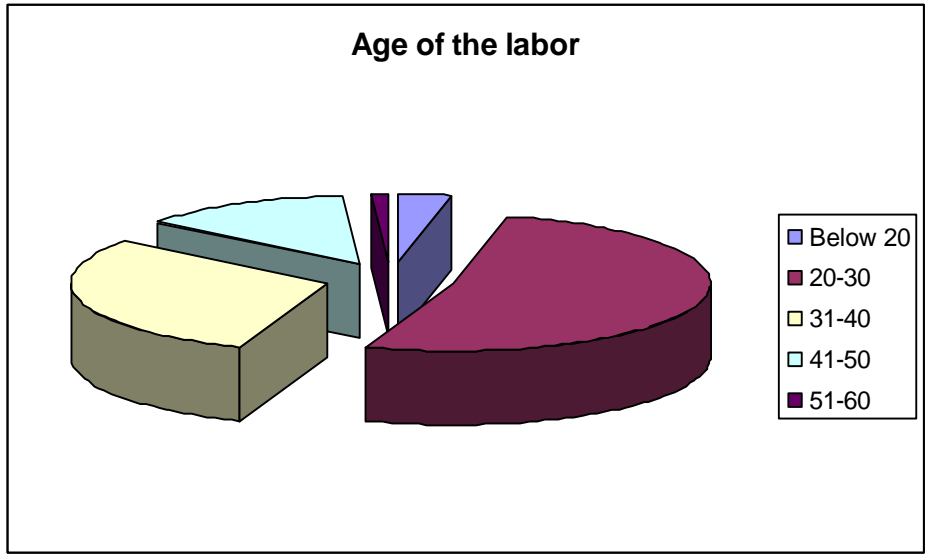

Figure 2: Age of labor

Source: Constructed from Questionnaire Survey

\section{Number of family members}

The data show that, the maximum labor holds the members of four to six persons. Only four laborers hold eight to ten family members. On the other hand, out of the sample, 16 labors hold a very small family.

Table 3: Number of family members

\begin{tabular}{|c|c|}
\hline Family Members & No. of frequency \\
\hline $0-4$ & 16 \\
\hline $4-6$ & 63 \\
\hline $6-8$ & 7 \\
\hline $8-10$ & 4 \\
\hline Total & 90 \\
\hline
\end{tabular}

Source: Constructed from Questionnaire Survey

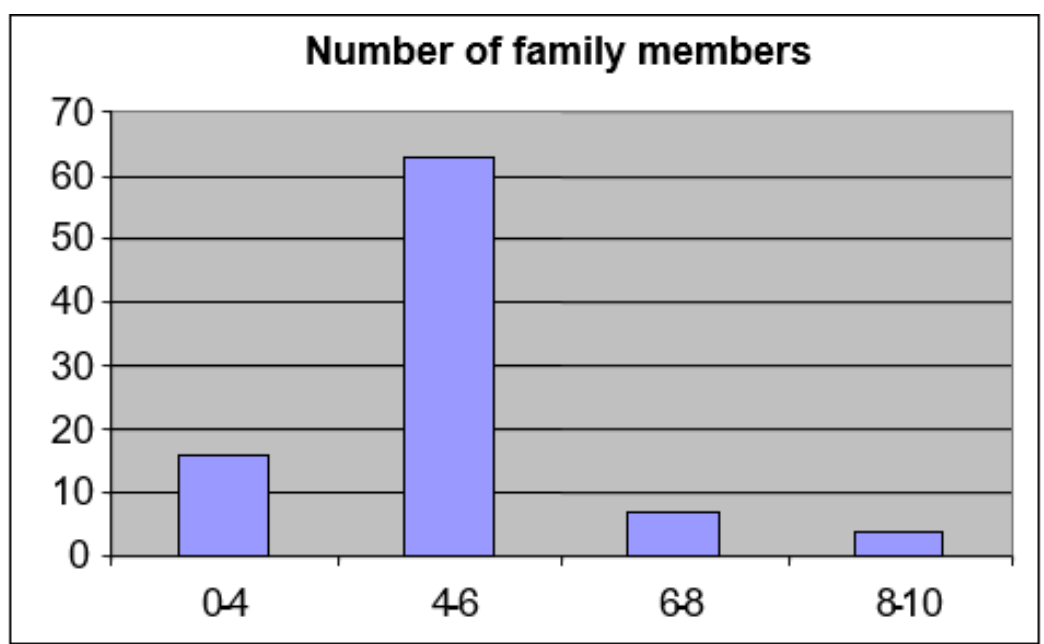

Figure 3: number of family members

Source: Constructed from Questionnaire Survey 


\section{Number of Children}

There are $25 \%$ of labor who are still unmarried, and 3\% of married labor have no children, $16 \%$ of labor have only one child, $58 \%$ of labor have two to four children, and only $2 \%$ of labor have more than four children.

Table 4: Number of children of the migrant labor

\begin{tabular}{|c|c|}
\hline Number of Children & No. of frequency \\
\hline 0 & 20 \\
\hline$<2$ & 15 \\
\hline $2-4$ & 53 \\
\hline$>4$ & 2 \\
\hline Total & 90 \\
\hline
\end{tabular}

Source: Constructed from Questionnaire Survey

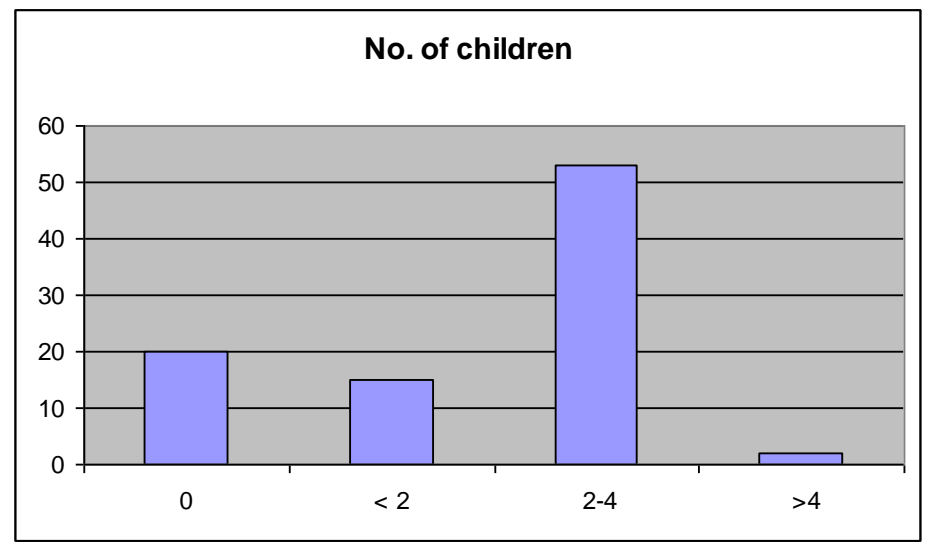

Figure 4: Number of children

Source: Constructed from Questionnaire Survey

\section{Educational Status of the Labor}

The maximum migrated laborers have no higher academic knowledge. $10 \%$ of labors have got no academic education, and only $10 \%$ of labors have completed primary education, $63 \%$ of labors haven't completed the secondary education. There are $47 \%$ of labor completed the certificate education, of which $4 \%$ of labors have obtained the master degree education.

Table 5: Educational Status

\begin{tabular}{|c|c|c|}
\hline Educational Status & No. of frequency & Proportion \\
\hline Uneducated & 9 & 0.1 \\
\hline Below class Five & 9 & 0.1 \\
\hline Class five to ten & 39 & 0.433333 \\
\hline SSC & 18 & 0.2 \\
\hline HSC & 7 & 0.077778 \\
\hline Graduated & 4 & 0.044444 \\
\hline Masters Degree Holder & 4 & 0.044444 \\
\hline & 90 & 1 \\
\hline
\end{tabular}

Source: Constructed from Questionnaire Survey 


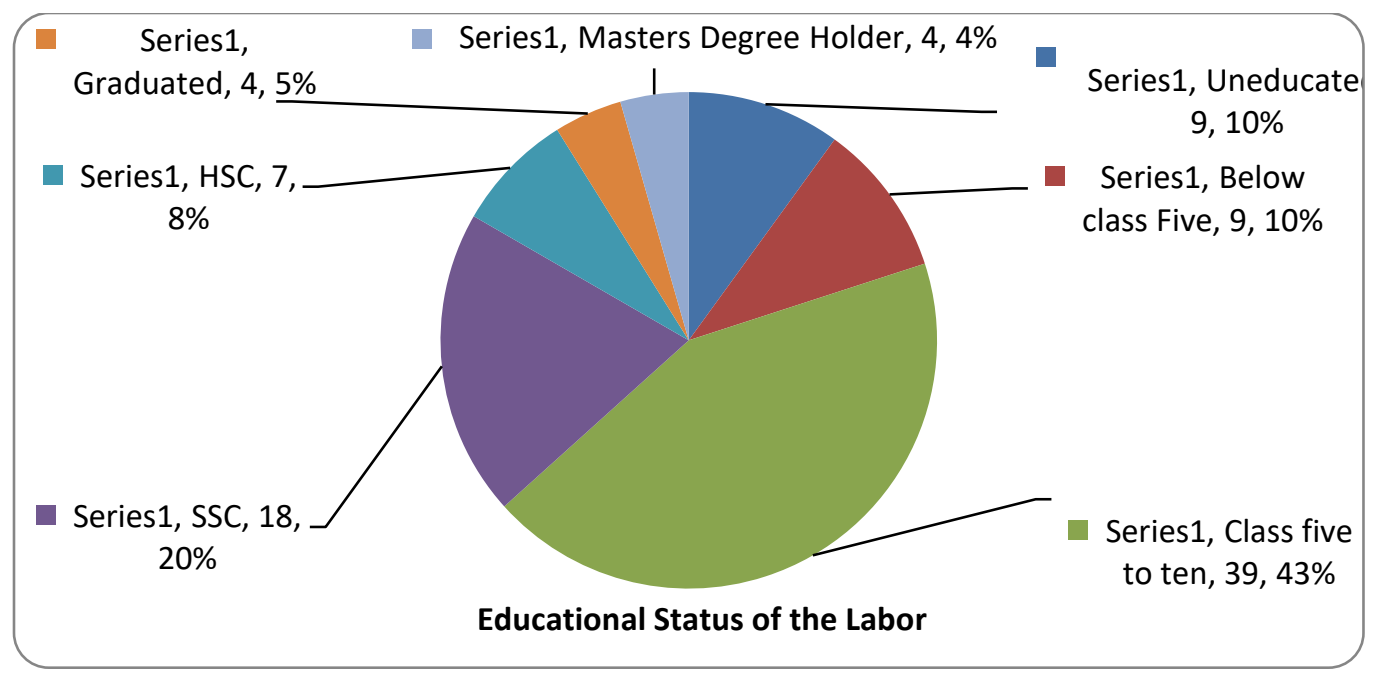

Figure 5: Educational status of the labor

Source: Constructed from Questionnaire Survey

\section{Nature of Labor}

The data shows the present situation of the labor. The nature of skills of the labor shows in the following table. It is very important that, the present data shows that the maximum labor is now skilled, but it is to be noted that when they were migrated, the maximum of them were unskilled.

The data shows that $7 \%$ of the labor is still unskilled, $24 \%$ of are semi-skilled, and the rest is skilled.

Table 6: Nature of skills

\begin{tabular}{|c|c|c|}
\hline Nature of Skills & No. of frequency & Probability \\
\hline Unskilled & 7 & 0.077778 \\
\hline Semi-skilled & 22 & 0.244444 \\
\hline Skilled & 61 & 0.677778 \\
\hline & 90 & 1 \\
\hline
\end{tabular}

Source: Constructed from Questionnaire Survey



Figure 6: Nature of labor

Source: Constructed from Questionnaire Survey 


\section{Marital status of the labor}

The maximum of migrated people are academically uneducated. So they do no intend to preserve their information properly. Not only that, they are not aware of their information rights. The information shows that, $9 \%$ of labors have no information about when they are migrated from their loving residence. There are $8 \%$ of labor who are migrated within the last three years. Fro the 2011 to 2015 period shows that, the maximum labors are migrated from this period, i.e., $37 \%$.

Table 7: When the labors are migrated?

\begin{tabular}{|c|c|c|}
\hline When the labors are migrated & No. of frequency & Probability \\
\hline Don't Have in Mind & 8 & 0.088889 \\
\hline Before 2000 & 5 & 0.055556 \\
\hline $2000-2005$ & 11 & 0.122222 \\
\hline $2006-2010$ & 25 & 0.277778 \\
\hline $2011-2015$ & 34 & 0.377778 \\
\hline After 2015 & 7 & 0.077778 \\
\hline Total & 90 & 1 \\
\hline
\end{tabular}

Source: Constructed from Questionnaire Survey

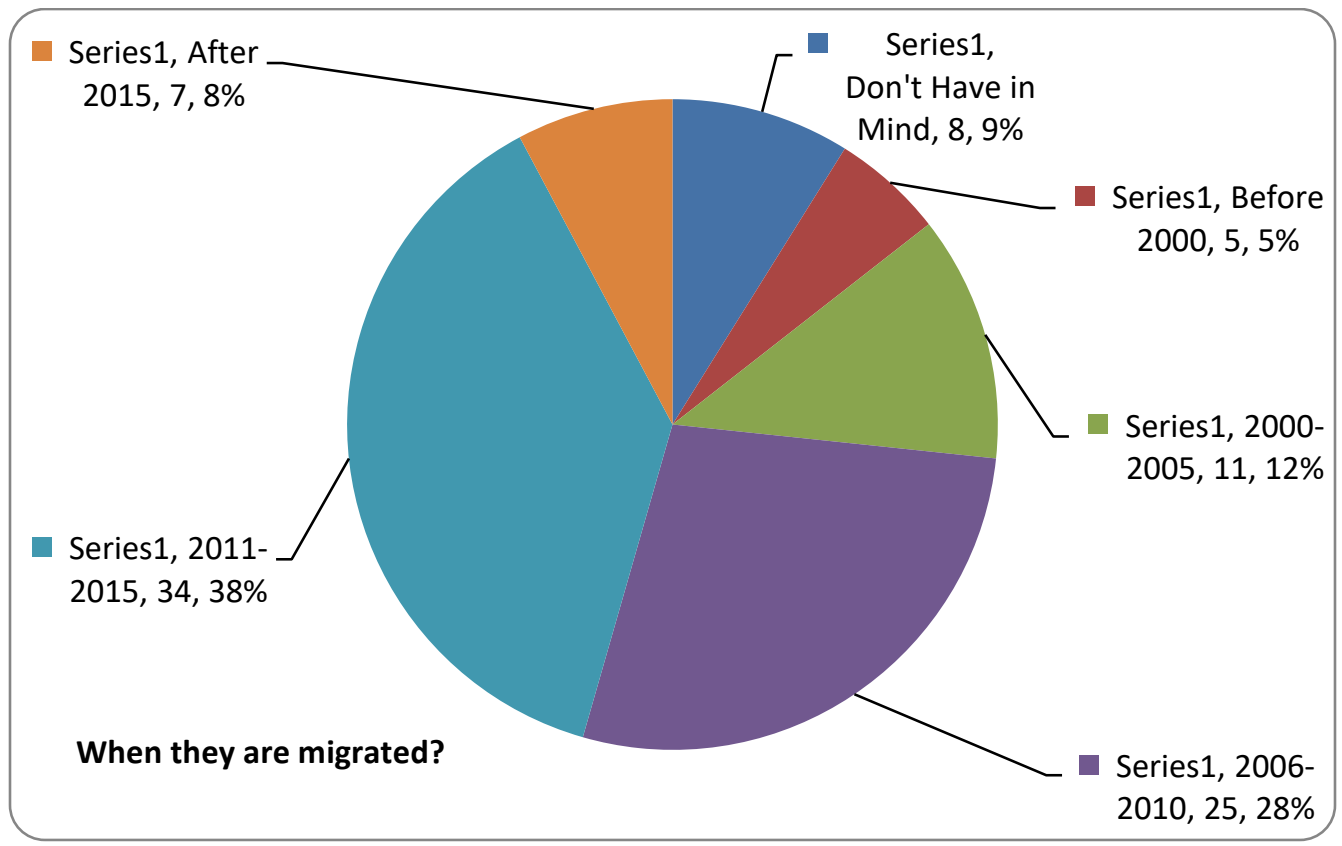

Figure 7: When the labors are migrated?

Source: Constructed from Questionnaire Survey

\section{Profession before Migration}

Nobody wants to leave his residence. In any conditions, he would like service in his residence. In the survey research, it is found that $33 \%$ of migrated labor were day labor. $15.56 \%$ of labor were unemployed, the same percentage of people were farmers and students before the migration. There were also some percentage shopkeepers, housewifes, rickshaw puller, garment worker, tailor, business people who were migrated. 
Table 8: Profession before migration

\begin{tabular}{|l|c|c|}
\hline Profession & No. of frequency & $\mathbf{\%}$ \\
\hline Unemployed & 14 & 15.56 \\
\hline Day Labor & 30 & 33.33 \\
\hline Farmer & 14 & 15.56 \\
\hline Student & 14 & 15.56 \\
\hline Shopkeeper & 2 & 2.22 \\
\hline Housewife & 3 & 3.33 \\
\hline Rickshaw Puller & 2 & 2.22 \\
\hline Garment worker & 2 & 2.22 \\
\hline Tailor & 3 & 3.33 \\
\hline Business & 2 & 2.22 \\
\hline Other & 4 & 4.44 \\
\hline Total & 90 & 100.00 \\
\hline
\end{tabular}

Source: Constructed from Questionnaire Survey

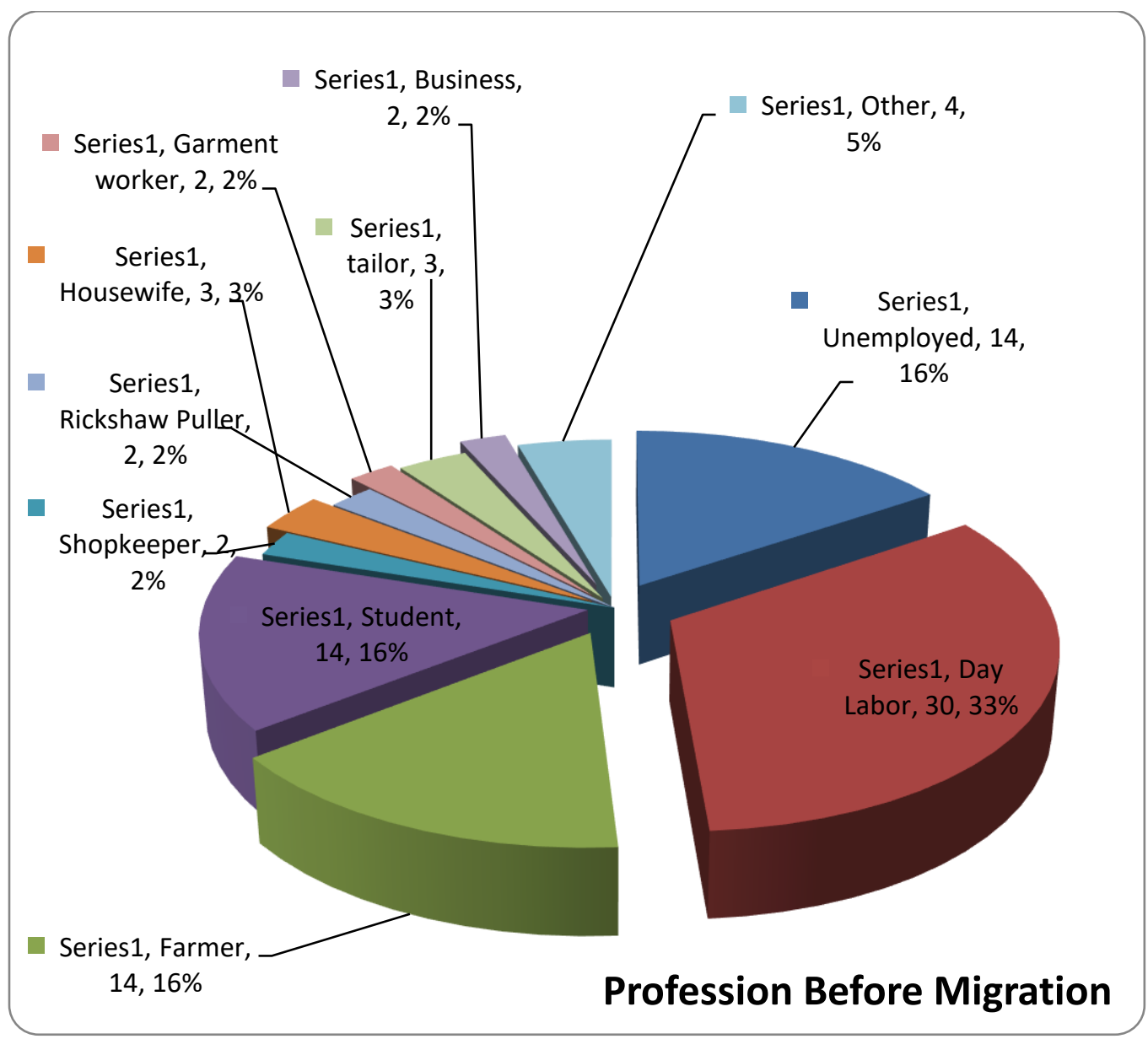

Figure 8: Profession before migration

Source: Constructed from Questionnaire Survey 


\section{Income per day}

There were high expectations to the migrated labor that, living standard will be enriched with the new profession. They leave their residence for the better income. It is observed that there were $35.56 \%$ of people with zero income level per day. On the other hand, after the migration there are no people with nil income. The data shows that $25.56 \%$ of labor's income was 100 to $150 \mathrm{Tk}$. , but after the migration $44.44 \%$ of labor's income was increased to 400 to $600 \mathrm{Tk}$.

Table 9: Income per day

\begin{tabular}{|c|c|c|c|c|c|}
\hline \multicolumn{7}{|c|}{ Income per day } \\
\hline Before Migration & Frequency & $\%$ & Before Migration & Frequency & $\%$ \\
\hline 0 & 32 & 35.56 & 0 & 0 & 0.00 \\
\hline $0-50$ & 3 & 3.33 & $200-400$ & 36 & 40.00 \\
\hline $50-100$ & 12 & 13.33 & $400-600$ & 40 & 44.44 \\
\hline $100-150$ & 23 & 25.56 & $600-1000$ & 12 & 13.33 \\
\hline $150-200$ & 11 & 12.22 & Above 1000 & 2 & 2.22 \\
\hline $200-250$ & 6 & 6.67 & & & \\
\hline above 250 & 3 & 3.33 & & & \\
\hline & 90 & 100.00 & & 90 & 100.00 \\
\hline
\end{tabular}

Source: Constructed from Questionnaire Survey

\section{Consumption pattern}

The consumption pattern is very important to identify the living standard of a people. The lower level people incur their expenditure to buy the inferior goods. After meeting the inferior goods we need to meet the necessary goods, and after that we meet our luxurious goods. In the earlier that means before the migration $81.11 \%$ of people incur their expenditure for buying the inferior goods and the rest of the people incur for the necessary goods still no one can consume the luxurious goods. On the other hand, after the migration only $4.44 \%$ of labors are availing the luxurious goods. So still they are not enjoying their life.

Table 10: Consumption pattern

\begin{tabular}{|c|c|c|c|}
\hline Before Migration & Frequency & Present & Frequency \\
\hline \hline Inferior goods & 73 & Inferior goods & 23 \\
\hline Necessary goods & 17 & Necessary goods & 63 \\
\hline Luxurious goods & 0 & Luxurious goods & 4 \\
\hline Total & 90 & Total & 90 \\
\hline
\end{tabular}

Source: Constructed from Questionnaire Survey

\section{Savings per month}

Income and savings are very positively related. If income is increased, and if the expenditure is constant then the savings is increased. If it is reversed then the effect will be reversed. Savings is the surplus of income over the expenditure. The savings pattern shows the real economic condition of a people. The data shows that before the migration $83.33 \%$ of people have no savings, but after migration that is reduced to $13.33 \%$. On the other hand, there were only $2.22 \%$ of people who saved above five thousand taka per month, but after the migration there are $85.55 \%$ of people who saved more than four thousand taka per month. 
Table 11: Savings per month

\begin{tabular}{|c|c|c|c|c|c|}
\hline \multicolumn{3}{|c|}{ Before migration } & \multicolumn{3}{c|}{ After migration } \\
\hline Savings & Frequency & $\%$ & Frequency & Savings & $\%$ \\
\hline 0 & 75 & 83.33 & 0 & 12 & 13.33 \\
\hline $500-1000$ & 10 & 11.11 & $400-600$ & 1 & 1.11 \\
\hline $1000-2000$ & 2 & 2.22 & $2000-4000$ & 38 & 42.22 \\
\hline $4000-5000$ & 1 & 1.11 & $4000-6000$ & 28 & 31.11 \\
\hline above 5000 & 2 & 2.22 & $6000-8000$ & 9 & 10.00 \\
\hline & & & above 12000 & 2 & 2.22 \\
\hline & & 100.00 & & & 90 \\
\hline
\end{tabular}

Source: Constructed from Questionnaire Survey

\section{Investment per month}

The relationship between savings and investment is like the relationship between income and savings. Investment is part of savings. So, if the income is increased, then the savings is increased and then the investment is increased. So, there is a positive relationship between income, savings and investment. So, finally it is to be concluded that the investment pattern is the final status. The data are shown the detail of the investment pattern of a migrated labor.

Table 12: Investment per month

\begin{tabular}{|c|c|c|c|c|c|}
\hline \multicolumn{3}{|c|}{ Before migration } & \multicolumn{3}{c|}{ After migration } \\
\hline \hline Investment & Frequency & $\%$ & Investment & Frequency & $\%$ \\
\hline \hline 0 & 79 & 87.78 & 0 & 26 & 28.89 \\
\hline $500-1000$ & 8 & 8.89 & $2000-4000$ & 40 & 44.44 \\
\hline $1000-2000$ & 2 & 2.22 & $4000-6000$ & 15 & 16.67 \\
\hline $3000-4000$ & 1 & 1.11 & $6000-8000$ & 6 & 6.67 \\
\hline & & 0.00 & above 12000 & 3 & 3.33 \\
\hline Total & 90 & 100.00 & Total & 90 & 100.00 \\
\hline
\end{tabular}

Source: Constructed from Questionnaire Survey

\section{Child-education, shelter and medical facilities}

The lower-level people were very much dissatisfied with their facilities. They were not satisfied with their Child-education, shelter and medical facilities. Before the migration they are $9 \%$ of people who are extremely dissatisfied with these types of facilities, and $33.33 \%$ of people were very dissatisfied. On the other hand, there are $23.33 \%$ of laborers who are very pleased with their medical facilities, shelter and child education facilities.

Table 13: satisfaction level

\begin{tabular}{|c|c|c|c|c|r|}
\hline \multicolumn{2}{|c|}{ Before migration } & \multicolumn{2}{c|}{ After migration } \\
\hline Level of satisfaction & Frequency & $\%$ & Level of satisfaction & Frequency & $\%$ \\
\hline extremely displeased & 8 & 8.89 & very pleased & 21 & 23.33 \\
\hline very Displeased & 30 & 33.33 & extremely pleased & 3 & 3.33 \\
\hline Neutral & 27 & 30.00 & Neutral & 14 & 15.56 \\
\hline pleased & 7 & 7.78 & pleased & 41 & 45.56 \\
\hline Other & 18 & 20.00 & Other & 11 & 12.22 \\
\hline Total & 90 & 100.00 & Total & 90 & 100.00 \\
\hline
\end{tabular}

Source: Constructed from Questionnaire Survey 


\section{Reasons for migration}

In the earlier, it is mentioned that, nobody wants to leave his residence. However, in some cases they are bound to leave their residence for survival. There are two types of factors for which they are migrated for their existence. The push factor for which the labor pushed to another location is lack of services, poverty, etc. The result shows that, $41 \%$ of people are pushed for migration. On the other hand, pull factors are those for which people are pulled to provide them more. In some cases, the people are pulled by some incentive, i.e., more wealth, higher employment and better services.

Table 14: reasons for migration

\begin{tabular}{|c|c|c|c|}
\hline Push Factors & No. of frequency & Pull factors & No. of frequency \\
\hline Lack of services & 20 & More wealth & 12 \\
\hline Poverty & 37 & Higher employment & 19 \\
\hline Other & 33 & Better Services & 12 \\
\hline & & Other & 47 \\
\hline Total & 90 & Total & 90 \\
\hline
\end{tabular}

Source: Constructed from Questionnaire Survey

\section{Findings of the study}

i) Most of the migrated laborers are not academically higher knowledge. $63 \%$ of labors haven't completed the secondary education. There are $47 \%$ of labor completed the certificate education, of which $4 \%$ of laborers have obtained the master degree education.

ii) The maximum labor is now skilled, but it is to be noted that when they were migrated, maximum of them were unskilled. The data shows that $7 \%$ of the labor is still unskilled, $24 \%$ are semi-skilled, and the rest is skilled.

iii) There are $8 \%$ of labor who are migrated within the last three years. From the 2011 to 2015 period shows that, the maximum laborers are migrated from this period, i.e., $37 \%$.

iv) It is found that $33 \%$ of migrated labor were day labor. $15.56 \%$ of labor were unemployed, the same percentage of people were farmers and students before the migration. There were also some percentage shopkeepers, housewifes, rickshaw puller, garment worker, tailor, business people who were migrated.

v) It is observed that there were $35.56 \%$ of people with zero income level per day before their migration. On the other hand, after the migration there are no people with nil income. The data shows that $25.56 \%$ of labor's income was 100 to 150 Tk., but after the migration $44.44 \%$ of labor's income was increased to 400 to $600 \mathrm{Tk}$.

vi) Before the migration $81.11 \%$ of people incur their expenditure for buying the inferior goods and the rest of the people incur for the necessity goods, still no one can consume the luxurious goods. On the other hand, after the migration only $4.44 \%$ of labors are availing the luxurious goods. So still they are not enjoying their life.

vii) The findings shows that, before the migration $83.33 \%$ of people have no savings, but after migration that is reduced to $13.33 \%$. On the other hand, there were only $2.22 \%$ of people who saved above five thousand taka per month, but after the migration there are $85.55 \%$ of people who saved more than four thousand taka per month. 
viii) Before the migration they are $9 \%$ of people who are extremely dissatisfied with these types of facilities, and $33.33 \%$ of people were very dissatisfied. On the other hand, there are $23.33 \%$ of laborers who are very pleased with their medical facilities, shelter and child education facilities.

ix) The result shows that, $41 \%$ of people are pushed for migration. On the other hand, pull factor are those for which people are pulled to provide them more. In some cases, the people are pulled by some incentive, i.e., more wealth, higher employment and better services.

\section{CONCLUSION}

For this study the data is collected through different sets of questionnaires and most of the respondents may not like it to communicate the information. The financial conditions of the migrant labor regarding the present and past are collected for the study purposes, but it was not so easy to collect the true past data, because that data is not in a written form, the respondent recall the information and then it is noted. So there is a chance that the past data of the respondent may not be perfectly true. Labor force is the main component of the production. The quality of production, productivity, and efficiency depends on the labor satisfaction. Labor's living standard plays a great role for the sustainable production. So, for the proper economic growth in the sustainable economic development, living standard of a labor is very high considerable factors. It is assumed that, there is a great impact of labor mobilization on the living standard. The labor is migrated to have a better living standard. There are two ways, we have to provide the job opportunities near their residence, and if it is not possible then we have to provide the better living standard for the migrated people.

\section{REFERENCES}

Abella, M. (2013). Effects of Labour Mobility: An Analysis of Recent International Development Literature. The International Indigenous Policy Journal,4(3), 1-40. https://doi.org/10.18584/iipj.2013.4.3.3

Bing, L. (2011). The Study of Labor Mobility and its Impact on Regional Economic Growth. $\begin{array}{lll}\text { Procedia Environmental } & \text { Sciences, } & \text { 922-928. }\end{array}$ https://doi.org/10.1016/j.proenv.2011.09.148

Briggs, V. M. (1994). International Migration and Labor Mobility: The Receiving Countries. Center for Advanced Human Resource Studies, Working Paper 94-19, 1-41. https://hdl.handle.net/1813/77106

Chowdhury, M. K. I., Rahman,M. M. and Faruque, O. (2010). A Socio-Economic Survey of Rice Farmers in Barind Area during Aman and Boro Season, Banglavision (An International Research Journal), 2(1).

David, A. \& Marouani, M. A. (2013). The impact of labor mobility on unemployment: a comparison between Jordan and Tunisia. Working Papers 823, Economic Research Forum. https://ideas.repec.org/p/erg/wpaper/823.html

Faruque, O. (2021). Socio-economic Conditions of Flood Affected People of Northern Districts in Bangladesh. ABC Journal of Advanced Research, 10(2), https://doi.org/10.18034/abcjar.v10i2.587

Faruque, O. and Ali, M. R., (2016). Factors Affecting the Choice of Agribusiness Model: A Study of the Northern area of Bangladesh. Journal of Business Research, 1(2). 
Faruque, O., \& Rahman, M. M. (2021). Development of Small Scale Industry in Rangpur Division of Bangladesh: Employee Perception. Asian Journal of Humanity, Art and Literature, 8(1), 43-54. https://doi.org/10.18034/ajhal.v8i1.572

Faruque, O., \& Rahman, M. M. (2021). Development of Wholesale and Retail Trade, Repair of Motor Vehicles and Motorcycles Business in Rangpur Division. ABC Journal of Advanced Research, 10(1), 39-56. https://doi.org/10.18034/abcjar.v10i1.569

Faruque, O., \& Siddiqua, A. (2019). Challenges and Opportunities of Grocery Business: A Study on Rangpur City Corporation in Bangladesh. Global Disclosure of Economics and Business, 8(1), 49-60. https://doi.org/10.18034/gdeb.v8i1.97

Hossain, M. M. (2010). Skilled and Unskilled Labor Migration and Poverty Reduction in Bangladeshan Econometric Analysis. http://bea-bd.org/site/images/pdf/29.pdf

International Labor Organization. (2015), The Contribution of Labor Mobility to Economic Growth, Organisation for Economic Co-operation and Development World Bank Group, Joint paper for the 3rd meeting of G20 Employment Working Group Cappadocia, Turkey. 23-25 July. https://shorturl.at/gqHNQ

International Labor Organization. (2015). The Contribution of Labor Mobility to Economic Growth, Organisation for Economic Co-operation and Development World Bank Group, Joint paper for G20 Labor and Employment Ministers, Meeting Ankara, Turkey. 3-4 Sept. https://shorturl.at/rwyB9

Leeson, P. T. \& Gochenour, Z. (2015). The Economic Effects of International Labor Mobility. The Economics of Immigration: Market-Based Approaches, Social Science, and Public Policy. https://doi.org/10.1093/acprof:oso/9780190258788.003.0002

Ministry of Expatriates. (2020). Expatriates' Welfare and Overseas Employment, Bangladesh. https://shorturl.at/sxRX5

Rahman, S. U. (2014). Impacts of Flood on the Lives and Livelihoods of People in Bangladesh: A Case Study of a Village in Manikganj District. Dissertation, Department of Architecture, BRAC University. http://hdl.handle.net/10361/3802

Ratha, D., Mohapatra, S., Elina Scheja, E. (2013). Impact of Migration on Economic and Social Development: A review of evidence and emerging issues. Policy Research Working Papers, 5558. https://doi.org/10.1596/1813-9450-5558

Siddiqui, T. (2003). Migration as a Livelihood Strategy of the Poor: the Bangladesh Case. Refugee and Migratory Movements Research Unit, Dhaka University. https://shorturl.at/juNS7

Siddiqui, T. (2012). Impact of Migration on Poverty and Development. Refugee and Migratory Movements Research Unit (RMMRU), Working Paper 2. https://shorturl.at/frtP4

Srivastava, R. \& Sasikumar, S. K. (2003). An Overview of Migration in India, its Impacts and Key Issues. Proceedings of Regional Conference on Migration, Development and ProPoor Policy Choices in Asia, 22-24 June 2003 in Dhaka. http:// www.shram.org/uploadFiles/20131014063711.pdf

The Asia Foundation. (2013), Labor Migration trends and Patterns: Bangladesh, India, and Nepal 2013, http://www.shram.org/researchpapers/reports/20160411095013 
Wilson, E. J., Jayanthakumaran, K. and Verma, R. (2012). ADBI Working Paper Series: Demographics, Labor Mobility, and Productivity. Asian Development Bank Institute, Paper 387. https://www.adb.org/sites/default/files/publication/156242/adbiwp387.pdf 